\title{
Pengembangan Perangkat Pembelajaran Berbasis Pendekatan Matematika Realistik Untuk Meningkatkan Kemampuan Koneksi dan Kemandirian Belajar Siswa SMA Swasta Tunas Pelita Binjai
}

\author{
Nurliza Fahmi Lubis ${ }^{1}$, Bornok Sinaga $^{2}$, Mulyono $^{3}$ \\ ${ }^{1,2,3}$ Prodi Pendidikan Matematika Pascasarjana, Universitas Negeri Medan \\ Universitas Negeri Medan, Jalan William IskandarPasar V, Medan, Indonesia \\ nurliza.lubis@gmail.com
}

\begin{abstract}
The aims of this research are: (1) To find out the quality learning tools developed through realistic, practical, and effective mathematics-based learning approach; (2) Describing students' mathematical connection abilities through learning tools developed through realistic mathematics learning approaches; (3) Describing student learning independence through learning tools developed through realistic mathematics-based learning; (4) Knowing students' responses to learning tools developed through learning based on a realistic mathematics approach. This research is development research. The learning device development model in this study was adapted from a 4-D The research instrument used was a validation sheet, an assessment sheet for learning devices, and an observation sheet on the implementation of learning, a mathematical connection test, and a learning independence scale. Validity data analysis and practicality data analysis were respectively carried out by converting quantitative data in the form of assessment scores into qualitative data in the form of standard values. Data analysis of the effectiveness of the mathematical connection test was carried out by determining the percentage of minimum completeness, while the learning independence scale was viewed from the increase in learning. The average achievement of students' mathematical connection abilities in the first trial was $81.25 \%$, increasing to $90.63 \%$ in the second trial. In addition, the average of each indicator of mathematical connection ability increased from trial I to trial II.
\end{abstract}

Keywords: Learning tools, Realistic Mathematics Approach, Mathematical Connection, Independent Learning

\begin{abstract}
Abstrak
Tujuan penelitian ini adalah: (1) Mengetahui perangkat pembelajaran berkualitas yang dikembangkan melalui pembelajaran berbasis pendekatan matematika realistic valid, prakis, dan efektif; (2) Mendeskripsikan kemampuan koneksi matematis siswa melalui perangkat pembelajaran yang dikembangkan melalui pembelajaran pendekatan matematika realistic; (3) Mendeskripsikan kemandirian belajar siswa melalui perangkat pembelajaran yang dikembangkan melalui pembelajaran berbasis pendekatan matematika realistic; (4) Mengetahui respon siswa terhadap perangkat pembelajaran yang dikembangkan melalui pembelajaran berbasis pendekatan matematika realistik. Penelitian ini merupakan penelitian pengembangan. Model pengembangan perangkat pembelajaran dalam penelitian ini diadaptasi dari model pengembangan 4-D. Instrument penelitian ini yang digunakan adalah lembar validasi, lembar penilaian terhadap perangkat pembelajaran, dan lembar observasi terhadap pelaksanaan pembelajaran, tes koneksi matematis, dan skala kemandirian belajar. Analisis data kevalidan dan analisis data kepraktisan masing-masing dilakukan dengan menkonversi data kuantitatif berupa skor hasil penilaian menjadi data kualitatif berupa nilai standar. Analisis data keefektifan tes koneksi matematis dilaksanakan dengan cara menentukan persentase ketuntasan minimal, sedangkan skala kemandirian belajar ditinjau dari peningkatan belajarnya. Rata-rata pencapaian kemampuan koneksi matematis siswa pada uji coba I sebesar 81,25\% meningkat menjadi 90,63\% pada uji coba II. Disamping itu, rata-rata setiap indikator kemampuan koneksi matematis meningkat dari uji coba I ke uji coba II.
\end{abstract}

Kata kunci: Perangkat pembelajaran, Pendekatan Matematika Realistik, Koneksi Matematis, Kemandirian Belajar

Copyright (c) 2022 Nurliza Fahmi Lubis, Bornok Sinaga, Mulyono

$\triangle$ Corresponding author: Nurliza Fahmi Lubis

Email Address: nurliza.lubis@gmail.com (Jalan William Iskandar Pasar V, Medan, Indonesia)

Received 09 January 2022, Accepted 07 February 2022, Published 08 February 2022

\section{PENDAHULUAN}

Salah satu bidang studi yang mendukung perkembangan ilmu pengetahuan dan teknologi adalah matematika. Pelajaran matematika sangat perlu diberikan kepada semua peserta didik untuk 
membekali peserta didik dengan kemampuan berpikir logis, analitis, sistematis, kritis, dan kreatif, serta kemampuan bekerjasama. Kompetensi tersebut diperlukan agar peserta didik dapat memiliki kemampuan memperoleh, mengelola, dan memanfaatkan informasi untuk bertahan hidup pada keadaan yang selalu berubah, tidak pasti, dan kompetitif.

Tujuan pembelajaran matematika yang tertuang dalam peraturan Menteri Pendidikan Nasional No. 23 tentang Standar Isi (Depdiknas, 2006), yaitu (1) memahami konsep matematika, menjelaskan hubungan antar konsep dan menerapkan konsep dan algoritma, secara sistematis, akurat, efisien, dan tepat dalam memyelesaikan masalah; (2) menggunakan logika berpikir pada pola dan sifat melakukan manipulasi matematika dalam membuat generalisasi, menyusun bukti, atau menjelaskan ide dan pernyataan matematika; (3) menyelesaikan masalah yang meliputi kemampuan memahami masalah, membuat model matematika, menyelesaikan model dan menerjemahkan solusi yang diperoleh; (4) mengkomunikasikan gagasan dengan simbol, tabel, diagaram atau media lain untuk memperjelas keondisi atau masalah; (5) mempunyai sikap menghargai kegunaan matematika dalam kehidupan, yaitu memiliki rasa ingin tahu, perhatian dan minat dalam memahami matematika, serta sikap gigih dan percaya diri dalam pemecahan masalah.

Berdasarkan hasil wawancara dengan Ibu Nita Wulansari, S. Pd, guru matematika di SMA Swasta Tunas Pelita Binjai pada tanggal 6 September 2021 tentang kendala yang dihadapi guru dalam pembelajaran matematika, Beliau menyatakan bahwa siswa sering kesulitan jika mengerjakan soal yang penyelesainnya berkaitan dengan materi matematika lain yang telah dipelajari. Selain itu siswa kesulitan jika diberikan soal berita yang berkaitan dengan kehidupan sehari-hari. Soal-soal matematik yang semacam ini disebut soal koneksi matematik. Hal ini dapat dilihat pula dari penelitian yang dilakukan oleh (Danaryanti \& Dara, 2016) yang meneliti kemampuan koneksi matematik pada kelas VIII SMP yang menghasilkan nilai pencapaian rata-rata kemampuan koneksi matematik siswa SMP hanya $63.3 \%$.

Soal koneksi matematik bisa dilatih pengerjaanya dengan mengembangkan kemampuan koneksi matematik siswa. Rismawati, dkk (Rismawati et al., 2016) menyatakan bahwa : NCTM (2000) menjelaskan bahwa standar koneksi di sekolah prekindergarten sampai kelas XII diharapkan peserta didik dapat : (1) mengetahui dan menggunakan koneksi antara ide-ide matematika, (2) memahami bagaimana ide matematika berhubungan dan menyatukan satu sama lain untuk menghasilkan hasil keseluruhan, serta (3) mengetahui dan menerapkan matematika dalam konteks di luar matematika.

Selain itu Henriana, Slamet \& Sumarmo (Henriana, 2014) menyatakan ; "mathematical connection helps students provide a mathematical model that illustrates the relationship among concepts, data, and situation". Kutipan ini bermakna bahwa koneksi matematik membantu peserta didik merancang model matematika yang menggambarkan hubungan antar konsep, data dan situasi. Siswa mampu menghubungkan konsep matematika namun salah menentukan konsepnya. 
Kesalahan menghubungkan konsep menghasilkan jawaban yang salah. Selain aspek kognitif, aspek lain yang tidak kalah pentingnya yaitu aspek afektif (sikap). Melalui kurikulum 2013 yang dirancang dengan karakteristik mengembangkan keseimbangan antara sikap spiritual dan sosial, pendidikan di Indonesia tidak hanya fokus pada sisi pengetahuan melainkan kegiatan pembelajaran di sekolah diselenggarakan untuk mengembangkan sikap, pengetahuan, dan ketrampilan siswa. Salah satu sikap yang diharapkan dapat berkembang melalui pelaksanaan pendidikan adalah mandiri (Aulia et al., 2019). Kemandirian adalah kemampuan yang dimiliki seseorang untuk melakukan sesuatu dan dapat mempertanggungjawabkannya (Fadhillah, N., \& Faradina, 2016). Kemandirian dapat diterapkan dalam banyak hal, salah satunya adalah kemandirian belajar.

Kemandirian belajar siswa sangatlah penting dalam pembelajaran. Dalam perkembangannya, kemandirian belajar dipengaruhi oleh faktor yang berasal dari dalam diri maupun dari luar diri siswa. Aisah, Kurniasih, dan Fitriani (Aisah et al., 2018) menjelaskan bahwa faktor internal yang mempengaruhi kemandirian belajar siswa yaitu aspek disiplin, motivasi, tanggung jawab, inisiatif, dan percaya diri. Hal ini selaras dengan Dewi (Dewi, 2020) yang menyatakan bahwa terdapat lima aspek dari dalam diri seseorang yang mempengaruhi kemandirian belajarnya, diantaranya yaitu (1) disiplin; (2) percaya diri; (3) motivasi; (4) inisiatif; dan (5) tanggung jawab.

Dalam menumbuh kembangkan kemampuan koneksi dan kemandirian belajar perlu adanya inovasi dan alternative dalam menyelesaikan masalah tersebut. Salah satu kunci adalah peningkatan mutu guru. Pemerintah melakukan banyak program untuk meningkatkan mutu guru, tetapi upaya tersebut akan sia-sia jika guru-guru sebagai tokoh penting dalam pendidikan tidak meningkatkan kualitas dirinya. Praktik pembelajaran yang dilaksanakan, ternyata belum ada upaya guru untuk meningkatkan motivasi dan hasil belajar siswa baik itu dalam kegiatan diskusi maupun praktikum. Hal ini tentu ada pengaruhnya terhadap pemahaman guru terhadap perangkat. Kurangnya pemahaman guru terhadap perangkat pembelajaran membuat siswa tidak terlibat secara aktif dalam pembelajaran, sehingga pembelajaran terasa membosankan dan monoton. Berdasarkan akar permasalahan tersebut maka perlu dikembangkan perangkat model pembelajaran melalui metode penelitian pengembangan (Yohanis, J., Triwiyono, Modouw, 2013). Guru harus mampu mengembangkan perangkat pembelajaran yang efektif dan menarik agar siswa mempunyai respon positif terhadap pembelajaran yang disampaikan. Kreativitas dalam mengembangkan sumber belajar sangat penting dengan mengembangkan perangkat pembelajaran yang sesuai dengan metode, strategi pembelajaran dan kemampuan yang ingin diperoleh dalam proses pembelajaran. Untuk itu, guru dituntut untuk mempersiapkan desain pembelajaran seperti mengembangkan perangkat pembelajaran.

Perangkat pembelajaran sangat perlu diimplementasikan dalam praktik pembelajaran di satuan pendidikan. Akan tetapi, praktik pembelajaran sehari-hari di sekolah masih mengalami berbagai masalah yang berkenan dengan perangkat pembelajaran yang digunakan dalam proses pembelajaran. Hal ini sejalan dengan penelitian yang dilakukan oleh Yuliani, Tindangen, Rambitan (Yuliani et al., 2016) bahwa pemahaman guru terhadap perangkat pembelajaran berupa silabus, RPP, 
bahan ajar, media pembelajaran, LKS, dan evaluasi masih sangat minim bahkan tidak mencapai 50 persen sehingga pemanfaatannya pun masih kurang optimal. Pada gambar tersebut terlihat dimana pemahaman guru terkait silabus dengan presentase sebesar 41\%, RPP sebesar 27\%, bahan ajar sebesar 14\%, media pembelajaran sebesar 9\%, LKS sebesar 5\%, dan evaluasi sebesar $4 \%$.

Dari paparan di atas, terlihat bahwa permasalahan rendahnya kemampuan koneksi dan kemandirian belajar dapar diselesaikan dengan menyediakan perangkat pembelajaran yang memenuhi kriteria valid, praktis dan efektif serta berfokus untuk meningkatkan kedua kemampuan tersebut. Dalam pengembangan perangkat, hendaknya guru memilih pendekatan pembelajaran yang sesuai dengan tujuan yang hendak dicapai. Dalam hal ini bertujuan untuk meningkatkan kemampuan koneksi dan kemandirian belajar siswa.

Salah satu pendekatan pembarlajaran yang dapat digunakan guru pada proses pembelajaran adalah realistik. Dalam matematika, pendekatan realistic dinyatakan sebagai pembelajaran matematika realistic, dimana didalam proses belajarnya siswa diberikan kesempatan untuk memahami dan menemukan sendiri konsep-konsep matematika, lalu dipandu oleh guru untuk memperbaiki konsep- konsep matematika, lalu dipandu oleh guru untuk memperbaiki konsep yang salah dipahami oleh siswa. Hal ini sesuai dengan pernyataan Dickinson \& Hough (Dickinson, P \& Hough, 2012) bahwa pendidik yang memakai matematika realistik mengatakan bahwa matematika realistik dapat menambah pemahaman peserta didik dalam memahami dan menerapkan matematika.

Berawal dari lemahnya kemampuan koneksi matematik dan kemandirian belajar serta pentingnya kedua hal tersebut berdasarkan pembelajaran matematika, serta hasil observasi lapangan yang menunjukkan bahwa kelemahan itu tidak lepas dari perangkat pembelajaran yang digunakan di lapangan, maka untuk menyelesaikan masalah yang ditemukan peneliti memberikan solusi berupa pengembangan perangkat pembelajaran berbasis model / pendekatan tertentu yang berfokus untuk meningkatkan kemampuan koneksi matematik dan kemandirian belajar siswa. Dalam hal ini pembelajaran yang dikembangkan pada penelitian ini meliputi RPP, LAS, Buku Siswa. Untuk itu, penelitian yang dilakukan adalah Pengembangan Perangkat Pembelajaran Matematika Realistik untuk Meningkatkan kemampuan Koneksi Matematika dan Kemandirian Belajar Siswa SMA Swasta Tunas Pelita Binjai.

\section{METODE}

Penelitian ini adalah penelitian pengembangan (development reseach) yang merupakan variasi dari Model Pembelajaran Thiagarajan dan Semmel (Thiagarajan, Semmel, 1974). Peneliti ingin mengembangkan perangkat pembelajaran berbasis pembelajaran matematika realistic yang meliputi; Rencana Pelaksanaan Pembelajaran, LKS, Buku Siswa, Instrumen Tes koneksi matematika, dan angket kemandirian belajar. Penelitian ini dilaksanakan di SMA Swasta Tunas Pelita Binjai semester genap tahun pelajaran 2021/2022. Subjek dalam penelitian ini adalah siswa Kelas XI SMA 
Swasta Tunas Pelita Binjai dan sebagai objek dalam penelitian ini adalah perangkat pembelajaran matematika pada materi program linear.

Penelitian pengembangan ini menggunakan model pengembangan perangkat pembelajaran Thiagarajan, semmel dan Semmel, yaitu model 4-D (define, design, develop, disseminate) yang telah dimodifikasi. Perangkat pembelajaran dengan pembelajaran matematika realistik yang meliputi Rencana Pelaksanaan Pembelajaran (RPP), buku siswa dan Lembar Aktivitaas Siswa (LAS). Selain itu juga dikembangkan instrument penelitian yang terdiri dari : lembar tes hasil kemampuan koneksi matematik siswa, lembar tes hasil kemandirian belajar siswa, lembar respon siswa, dan lembar validasi perangkat pembelajaran.

Tahap-tahap pengembangan perangkat pembelajaran 4-D yang telah dimodifikasi, antara lain :

\section{Tahap I: Define (Pendefinisian)}

Tahap define adalah tahap untuk menetapkan dan mendefinisikan syarat- syarat pembelajaran. Tahap define ini mencakup lima langkah pokok, yaitu analisis awal-akhir (front-end analysis), analisis siswa (leaner analysis), analisis tugas (task analysis) analisis konsep (concept analysis\}, dan perumusan tujuan pembelajaran (specifying instructional objectives).

\section{Tahap II: Design (Perancangan)}

Pada tahap ini dilakukan penyusunan draft awal untuk merancang contoh (prototype) perangkat pembelajaran untuk materi program linear dengan pembelajaran matematika realistik. Perangkat pembelajaran yang akan dihasilkan adalah buku siswa (BS), rencana pelaksanaan pembelajaran (RPP), lembar Aktivitas (LAS), tes kemampuan koneksi matematik dan kemandirian belajar.

\section{Tahap III: Develop (Pengembangan)}

Tahap pengembangan adalah tahap untuk menghasilkan perangkat pembelajaran yang akan dikembangkan. Selanjutnya dihasilkan Draft-Iyaitu perangkat pembelajaran yang telah direvisi berdasarkan masukkan para ahli. Kemudian perangkat yang sudah direvisi dan sudah baik menurut ahli, hasil dari revisi ahli disebut Draft-II. Draft-II kemudian diujicobakan ke lapangan kemudian dianalisis dan direvisi menghasilkan Draft-III atau Draft Final, sehingga diperoleh perangkat pembelajaran yang valid, praktis dan efektif.

\section{Tahap IV: Disseminate (Penyebaran)}

Pada tahap ini dilanjutkan penelitian yang lebih lanjut.

\section{HASIL DAN DISKUSI}

\section{Tahap Pendefinisian (Define)}

Berdasarkan hasil observasi dan analisis terhadap perangkat pembelajaran di SMA Swasta Tunas Pelita Binjai, memperlihatkan bahwa selama ini guru sudah baik namun belum spesifik mempunyai perangkat pembelajaran yang baik. Rencana Pelaksanaan Pembelajaran (RPP) yang ada bukan merupakan ilustrasi dari proses pembelajaran yang dilakukan dan masih hasil copy dari guru 
lain yang bersifat umum. Guru menggunakan buku yang tersedia di sekolah sebagai satu-satunya bahan ajar. LKS yang digunakan tidak sesuai dengan RPP, sehinggan tujuan pembelajaran yang ada di RPP tidak termuat didalam LKS. Masalah yang diberikan dalam menilai hasil belajar tidak mendukung pengembangan koneksi matematis, tidak terdapat rubrik penskoran pada penilaian hasil belajar. Proses pembelajaran juga kurang melibatkan siswa dalam menemukan pengetahuannya melainkan langsung diberikan oleh guru. Hal ini yang diduga penyebab kemampuan koneksi matematis dan kemandirian belajar siswa masih tergolong rendah.

\section{Tahap Perancangan (Design)}

Kegiatan pada tahap ini adalah penyusunan tes, pemilihan media, pemilihan format, dan desai awal perangkat pembelajaran. Tes yang dimaksud adalah tes koneksi matematis pada materi program linier dan angket kemandirian belajar. Tes koneksi matematis siswa terdiri dari 5 butir soal berbentuk uraian. Tes yang dikembangkan disesuaikan dengan jenjang kemampuan kognitif. Penskoran hasil tes menggunakan panduan evaluasi yang terdapat kunci dan pedoman penskoran setiap butir soal. Media pembelajaran yang disusun meliputi Rencana Pelaksanaan Pembelajaran (RPP), Buku Siswa (BS), Lembar Kegiatan Siswa (LKS), Tes Hasil Belajar berupa tes kemampuan koneksi matematis dan angket kemandirian belajar. Dengan menggunakan media dan alat pembelajaran diharapkan siswa dapat memahami dan menemukan konsep dan tugas yang diberikan.

\section{Tahap Pengembangan (Develop)}

Hasil dari tahap define dan design menghasilkan rancangan awal sebuah perangkat pembelajaran yang disebut dengan Prototype I. Setelah perangkat pembelajaran dengan pendekatan realistik didesain dalam bentuk Prototype I, maka dilakukan uji validitas terhadap pakar/ahli (expert review) dan uji coba lapangan.

Validasi merupakan langkah pertama pada tahap pengembangan. Validasi para ahli difokuskan pada format, isi, ilustrasi, dan bahasa pada perangkat pembelajaran yang dikembangkan. Hasil validasi ahli berupa nilai validasi, koreksi, kritik, dan saran yang digunakan sebagai dasar untuk melakukan revisi dan penyempurnaan perangkat pembelajaran.

Dari lembar validasi RPP, diperoleh bahwa rata-rata skor masing-masing aspek penilaian dari kelima validator adalah lebih besar atau sama dengan $4(\geq 4,0)$ dengan kriteria "valid". Rata-rata skor seluruhnya terhadap penilaian RPP sebesar 4,30 dengan kriteria "valid". Kelima validator menyimpulkan bahwa RPP dapat digunakan dengan revisi kecil. Dari penilaian para validator diperoleh koreksi, kritik, dan saran yang digunakan sebagai bahan pertimbangan dalam melakukan revisi rencana pelaksanaan pembelajaran.

Dari lembar validasi LKS, diperoleh bahwa rata-rata skor masing-masing aspek penilaian dari kelima validator adalah lebih besar atau sama dengan $4(\geq 4,0)$ dengan kriteria "valid". Rata-rata skor seluruhnya terhadap penilaian LKS berada pada kriteria valid, yaitu sebesar 4,30. Kelima validator menyimpulkan bahwa LKS dapat digunakan dengan revisi kecil. 
Berdasarkan data pada lembar validasi buku siswa, diperoleh rata-rata skor setiap aspek penilaian dari kelima validator berada pada nilai lebih besar atau sama dengan $4(\geq 4,0)$ dengan kriteria "valid". Keseluruhan rata-rata skor terhadap penilaian buku siswa berada pada kriteria "valid" yaitu sebesar 4,31. Kelima validator menyimpulkan bahwa buku ajar siswa dapat digunakan dengan revisi kecil.

Uji coba tes kemampuan koneksi matematis siswa bertujuan untuk mengetahui validitas dan reabilitas dari soal test kemampuan koneksi matematis. Hal ini akan mempengaruhi kesejajaran dengan skor total sehingga dapat digunakan sebagai alat evaluasi kemampuan koneksi matematis diakhir pembelajaran. Uji validitas dan reabilitas tes dilakukan melalui uji coba terhadap siswa yang lain dengan karakteritik yang sama. Berdasarkan rumus korelasi product moment, diperoleh validitas setiap butir pre-tes dan post-test disajikan pada Tabel 1. dan Tabel 2. sebagai berikut:

Tabel 1. Validitas Butir Pre-test Kemampuan Koneksi Matematis

\begin{tabular}{|l|l|l|l|l|}
\hline No & rxy & thitung & ttabel & Interpretasi \\
\hline 1 & 0,82 & 8,06 & 1,69 & Valid \\
\hline 2 & 0.73 & 6,02 & 1,69 & Valid \\
\hline 3 & 0,82 & 8,06 & 1,69 & Valid \\
\hline 4 & 0,73 & 6,02 & 1,69 & Valid \\
\hline 5 & 0,50 & 3,27 & 1,69 & Valid \\
\hline
\end{tabular}

Tabel 2. Validitas Butir Post-test Kemampuan Koneksi Matematis

\begin{tabular}{|l|l|l|l|l|}
\hline No & $\boldsymbol{r x y}$ & thitung & ttabel & Interpretasi \\
\hline 1 & 0,79 & 7,29 & 1,69 & Valid \\
\hline 2 & 0,81 & 7,82 & 1,69 & Valid \\
\hline 3 & 0,65 & 4,84 & 1,69 & Valid \\
\hline 4 & 0,74 & 6,22 & 1,69 & Valid \\
\hline 5 & 0,59 & 4,14 & 1,69 & Valid \\
\hline
\end{tabular}

Rangkuman Hasil validitas butir angket kemandirian belajar siswa terdapat pada Tabel 3. di bawah ini:

Tabel 3. Validitas Butir Angket Kemandirian Belajar siswa

\begin{tabular}{|c|l|l|l|l|}
\hline Butir soal & rxy & thitung & ttabel & Interpretasi \\
\hline 1 & 0,60 & 4,21 & 1,69 & Valid \\
\hline 2 & 0,61 & 4,30 & 1,69 & Valid \\
\hline 3 & 0,52 & 3,67 & 1,69 & Valid \\
\hline 4 & 0,49 & 3,49 & 1,69 & Valid \\
\hline 5 & 0,44 & 3,09 & 1,69 & Valid \\
\hline 6 & 0,48 & 3,38 & 1,69 & Valid \\
\hline 7 & 0,53 & 3,74 & 1,69 & Valid \\
\hline 8 & 0,51 & 3,61 & 1,69 & Valid \\
\hline 9 & 0,46 & 3,25 & 1,69 & Valid \\
\hline 10 & 0,36 & 2,54 & 1,69 & Valid \\
\hline 11 & 0,34 & 3,85 & 1,69 & Valid \\
\hline 12 & 0,51 & 3,60 & 1,69 & Valid \\
\hline 13 & 0,48 & 3,41 & 1,69 & Valid \\
\hline 14 & 0,46 & 3,22 & 1,69 & Valid \\
\hline 15 & 0,40 & 2,83 & 1,69 & Valid \\
\hline
\end{tabular}


Pengembangan Perangkat Pembelajaran Berbasis Pendekatan Matematika Realistik Untuk Meningkatkan Kemampuan Koneksi dan Kemandirian Belajar Siswa SMA Swasta Tunas Pelita Binjai, Nurliza Fahmi Lubis, Bornok Sinaga, Mulyono

\begin{tabular}{|l|l|l|l|l|}
\hline 16 & 0,56 & 3,98 & 1,69 & Valid \\
\hline 17 & 0,42 & 3,00 & 1,69 & Valid \\
\hline 18 & 0,43 & 3,03 & 1,69 & Valid \\
\hline 19 & 0,33 & 2,30 & 1,69 & Valid \\
\hline 20 & 0,54 & 3,79 & 1,69 & Valid \\
\hline
\end{tabular}

\section{Tahapan Penyebaran (Disseminate)}

Pengembangan perangkat pembelajaran matematika berbasis pendekatan realistik mencapai tahap akhir dimana perangkat pembelajaran matematika ini telah memperoleh penilaian positif dari tenaga ahli dan melalui tes pengembangan. Perangkat pembelajaran matematika berbasis pendekatan realistik dalam penelitian ini dilakukan penyebaran secara terbatas hanya pada sekolah mitra saja dari materi, kelas/siswa dan waktu (penyebaran khusus). Setelah perangkat final, perangkat pembelajaran matematika berbasis pendekatan realistik yang telah dikembangkan disebarkan untuk dapat digunakan pada semester berikutnya dalam materi perbandingan.

\section{Tingkat Penguasaan Siswa Terhadap Kemampuan Koneksi Matematis}

Tes kemampuan koneksi matematis dilakukan satu kali diawal sebelum kegiatan pembelajaran dimulai yang disebut dengan Pre-Test dan satu kali diakhir pembelajaran setelah melaksanakan empat kali pertemuan kegiatan belajar mengajar yang disebut dengan Post-Test. Pemberian Pre-Test dan Post-Test bertujuan untuk mengetahui peningkatan kemampuan koneksi matematis yang diperoleh siswa setelah diberi perlakuan pembelajaran dengan menggunakan pendekatan realistik pada materi program linier. Adapun data hasil uji coba lapangan untuk kemampuan koneksi matematis dapat dilihat pada Tabel 4. dibawah ini:

Tabel 4. Tingkat Ketuntasan Pre-Test dan Post-Test Kemampuan Koneksi Matematis Pada Uji Coba I

\begin{tabular}{|l|l|l|l|l|}
\hline \multicolumn{1}{|c|}{ Kategori } & Pre-Test & $\begin{array}{c}\text { Presentase } \\
\text { Ketuntasan } \\
\text { Klasikal }\end{array}$ & \multicolumn{1}{c|}{ Post-Test } & $\begin{array}{c}\text { Presentase } \\
\text { Ketuntasan } \\
\text { Klasikal }\end{array}$ \\
\hline Jumlah Siswa & 11 & \multicolumn{6}{|c|}{ Jumlah Siswa } \\
\hline Tuntas & $32,35 \%$ & 26 & $76,47 \%$ \\
\hline Tidak Tuntas & 23 & $67,65 \%$ & 8 & $23,53 \%$ \\
\hline Jumlah & 34 & 34 & $100 \%$ \\
\hline Rata-rata Kelas & $100 \%$ & 78,43 \\
\hline
\end{tabular}

Dari gambar diagram di atas dapat terlihat bahwa rata-rata kelas kemampuan koneksi matematis siswa pada pre-test uji coba I sebesar 64,90 sedangkan rata-rata kelas kemampuan koneksi matematis pada post-test uji coba I sebesar 78,43. Peningkatan kemampuan koneksi matematis pada uji coba I akan dilihat melalui $\mathrm{N}$-Gain dari hasil pre-test dan post-test kemampuan koneksi matematis pada uji coba I tersebut. 
Tabel 5. Rangkuman Hasil N-Gain Kemampuan Koneksi Matematis Uji Coba I

\begin{tabular}{|l|l|l|}
\hline Rata-rata N-Gain & Interpretasi & Jumlah Siswa \\
\hline $\mathrm{g}>0,7$ & Tinggi & 2 \\
\hline $0,3<\mathrm{g} \leq 0,7$ & Sedang & 17 \\
\hline $\mathrm{g} \leq 0,3$ & Rendah & 15 \\
\hline
\end{tabular}

Adapun data hasil uji coba II untuk kemampuan koneksi matematis dapat dilihat pada Tabel 6.

Tabel 6. Tingkat Ketuntasan Pre-Test dan Post-Test Kemampuan Koneksi Matematis Siswa Pada Uji Coba II

\begin{tabular}{|l|l|l|l|l|}
\hline Kategori & Pre-Test & $\begin{array}{l}\text { Presentase } \\
\text { Ketuntasan } \\
\text { Klasikal }\end{array}$ & Post-Test & $\begin{array}{l}\text { Presentase } \\
\text { Ketuntasan } \\
\text { Klasikal }\end{array}$ \\
\hline Jumlah Siswa & 17 & \multicolumn{5}{|l|}{ Jumlah Siswa } \\
\hline Tuntas & $50,0 \%$ & 30 & $88,2 \%$ \\
\hline Tidak Tuntas & 17 & $50,0 \%$ & 4 & $11,7 \%$ \\
\hline Jumlah & 34 & $100 \%$ & 34 & $100 \%$ \\
\hline Rata-rata Kelas & 69,90 & 84,51 & \\
\hline
\end{tabular}

Dari gambar diagram di atas dapat terlihat bahwa rata-rata kelas kemampuan koneksi matematis siswa pada pre-test uji coba II sebesar 69,90 sedangkan rata-rata kelas kemampuan koneksi matematis siswa pada post-test uji coba II sebesar 84,51. Peningkatan akan dilihat melalui $\mathrm{N}$-Gain dari hasil pre-test dan post-test kemampuan koneksi matematis pada uji coba II.

Tabel 7. Rangkuman Hasil N-Gain Kemampuan Koneksi Matematis UJi Coba II

\begin{tabular}{|c|c|c|}
\hline Rata-rata N-Gain & Interpretasi & Jumlah Siswa \\
\hline $\mathrm{g}>07$ & Tinggi & 4 \\
\hline $0,3<\mathrm{g} \leq 0,7$ & Sedang & 27 \\
\hline $\mathrm{g} \leq 0,3$ & Rendah & 3 \\
\hline
\end{tabular}

\section{Aspek Kemandirian Belajar Siswa}

1. Kepercayaan Diri

Berdasarkan hasil analisis pada butir angket nomor 1 pernyataan positif terdapat 13 orang atau $40 \%$ siswa sangat setuju, 19 orang atau 56,67\% setuju dan 2 orang atau 3,33\% tidak setuju, Butir angket nomor 2 dengan pernyataan negatif tidak terdapat atau $0 \%$ sangat setuju, 9 orang atau $26,7 \%$ setuju, 11 orang atau $33,3 \%$ tidak setuju dan 14 orang atau $40 \%$ sangat tidak setuju. Sementara butir angket nomor 3 dengan pernyatan negatif 3 orang atau 10\% sangat setuju, 15 orang atau 43,3\% setuju, 16 orang atau 46,67\% tidak setuju, butir angket nomor 4 pernyaataan 3 orang atau 10\% sangat setuju, 9 orang 26,7\% setuju, 9 orang atau 26,67\% tidak setuju dan 10 orang atau 30\% sangat tidak setuju, butir angket nomor 5,1 orang atau 3,33\% sangat setuju, 3 orang atau 6,67\% setuju, 18 orang atau 56,67\% tidak setuju dan 12 orang atau 33,3\% sangat tidak setuju. Artinya siswa lebih banyak memilih kepercayaan diri dalam menjalankan tugas dalam belajar. 
2. Keingintahuan

Berdasarkan hasil analisis pada butir nomor 7 pernyataan positif 2 orang atau 6,67\% sangat setuju dan 13 orang atau $40 \%$ setuju dan 17 orang atau 50\% tidak setuju, 2 orang atau 3,33\% sangat tidak setuju, butir nomor 9 pernyataan positif 21 orang atau 63,3\% sangat setuju dan 10 orang atau $30 \%$ setuju, 2 orang atau 3,3\% tidak setuju. Sedangkan butir nomor 8 pernyataan negatif 3 orang atau $6,67 \%$ setuju dan 18 orang atau 53,33\% tidak setuju dan 13 orang atau $40 \%$ sangat tidak setuju. Artinya lebih banyak siswa memilih menunjukkan keingintahuan untuk mendalami materi lebih jauh.

\section{Ketekunan}

Berdasarkan hasil analisis dapat diketahui bahwa butir nomor 10 dengan pernyataan positif 6 orang atau $16,7 \%$ sangat setuju, 4 orang atau $13,3 \%$ setuju dan 14 orang atau $40 \%$ tidak setuju, dan 10 orang sangat tidak setuju. Butir angket nomor 13 dengan butir pernyataan positif 16 orang atau 46,7\% sangat setuju, 17 orang atau 50\% setuju, dan 1 orang atau 3,3\% tidak setuju. Sedangkan pada butir angket nomor 11 pernyataan negatif 6 orang atau 16,7\% setuju, 15 orang atau 43,3\% tidak setuju dan 13 orang atau $40 \%$ sangat tidak setuju, serta butir angket nomor 12 pernyataan positif 13 orang atau $40 \%$ sangat setuju dan 19 orang atau 56,7\% setuju dan 2 orang atau 3,3\% tidak setuju. Artinya kebanyakan siswa memilih untuk tekun dalam meraih prestasi.

\section{Fleksibilitas}

Berdasalkan hasil analisis dapat diketahui butir angket nomor 6 dengan pernyataan positif 3 orang atau $10 \%$ sangat setuju, 17 orang atau 50\% setuju, 7 orang atau 20\% tidak setuju dan 7 orang atau 20\% sangat tidak setuju, butir nomor 16 dengan pernyataan positif 13 orang atau $40 \%$ sangat setuju dan 19 orang atau 56,7\% setuju, dan 2 orang atau 3,3\% sangat tidak setuju. Sedangkan butir angket nomor 14 dengan pernyataan negatif 6 orang atau 16,7\% sangat setuju, 6 orang atau 16,7\% setuju, 18 orang atau 53,3\% tidak setuju dan 4 orang atau 13,3\% sangat tidak setuju, serta angket nomor 15 dengan pernyataan negatif 3 orang atau $10 \%$ sangat setuju dan 8 orang atau 23,3\% setuju, 18 orang atau 53,3\% tidak setuju dan 5 orang atau 13,3\% sangat tidk setuju. Artinya kebanyakan siswa merasa penting.

\section{Reflektif dan Rasa Senang}

Berdasarkan hasil analisis dapat diketahui butir angket nomor 17 dengan pernyataan positif 8 orang atau 23,3\% sangat setuju dan 19 orang atau 56,7\% setuju, 3 orang atau $10 \%$ tidak setuju, 4 orang atau 6,7\% sangat tidak setuju. Butir angket nomor 20 dengan pernyataan positif 16 orang atau $46,7 \%$ sangat setuju, 15 orang atau 43,3\% setuju, 1 orang atau 3,3\% tidak setuju dan 2 orang atau $6,7 \%$ sangat tidak setuju. Sedangkan butir angket nomor 18 dengan pernyataan negatif 4 orang atau $13,3 \%$ setuju, 16 orang atau 46,7 tidak setuju, dan 14 orang atau $40 \%$ sangat tidak setuju serta butir angket nomor 19 dengan pernyataan negative 1 orang atau 3,3\% sangat setuju, 3 orang 6,7\% setuju, 12 orang atau $36,7 \%$ tidak setuju, dan 18 orang atau 53,3\% sangat tidak setuju. Artinya kebanyakan siswa yang memiliki rasa senang terhadap pembelajaran berbasis pendekatan realistik. 


\section{Diskusi}

\section{Pengembangan Perangkat Pembelajaran Matematika Berbasis Pendekatan Realistik Untuk Meningkatkan Kemampuan Koneksi Matematis}

Pembelajaran pada siswa SMA Swasta Tunas Pelita Binjai dengan rentang usia 12-15 tahun yang jika dirujuk pada pendapat Piaget, maka perkembangan kognitif siswa pada usia tersebut adalah tahap operasional formal. Dalam perkembangan terjadi proses asimilasi dan akomodasi. Asimilasi merupakan proses kognitif yang dengannya seseorang mengintegrasikan stimulus yang dapat mengubah persepsi, konsep, prinsip ataupun pengalaman baru ke dalam skema yang sudah ada dalam pikirannya sedangkan akomodasi dapat berupa pembentukan skema baru yang dapat cocok dengan ciri-ciri rangsangan yang ada atau memodifikasi skema yang cocok dengan ciri-ciri stimulus yang ada. Dalam pembelajaran diperlukan adanya penyeimbangan antara asimilasi dan akomodasi.

Proses pembelajaran yang dialami oleh siswa dalam penelitian ini telah melalui proses asimilasi dan akomodasi juga berada pada Zone of proximal development. Hal ini terlihat dari berhasil dikembangkannya suatu perangkat pembelajaran matematika pada materi program linier dengan menggunakan model pengembangan Thiagarajan, dkk yang lebih dikenal dengan model 4-D.

Perangkat pembelajaran yang dikembangkan dalam penelitian ini meliputi Rencana Pelaksanaan Pembelajaran (RPP), Buku Siswa (BS), Lembar Kegiatan Siswa (LKS), tes kemampuan koneksi matematis dan angket kemandirian belajar siswa. Seluruh perangkat pembelajaran yang dikembangkan ini menggunakan pembelajaran berbasis pendekatan realistik.

Sebelum perangkat pembelajaran diuji cobakan, peneliti terlebih dahulu memberikan tes prasyarat yang bertujuan untuk mengetahui pengetahuan awal siswa pada materi prasyarat tentang program linier. Hal ini bertujuan untuk melihat konsep awal siswa. Hal ini sesuai dengan Hudojo (Hudojo, 1994) yang menyatakan bahwa sebelum mempelajari konsep B, seseorang perlu memahami dulu konsep A yang mendasari konsep B. Sebab tanpa pemahaman konsep A, tidak mungkin orang itu memahami konsep B.

Berdasarkan hasil penelitian, dari pre-test diperoleh bahwa banyak siswa yang belum mampu dalam koneksi matematis. Pada pre-test diperoleh persentase ketuntasan klasikal siswa pada uji coba 1 yaitu $67,65 \%$ (23 siswa), sedangkan postest yaitu 23,53\% (8 orang) yang dikategorikan rendah dalam koneksi matematis. Berdasarkan masalah yang ditemukan pada pre-test dan postest pada uji coba I, maka diperlukan perbaikan dengan melanjutkan pada uji coba II untuk meningkatkan kemampuan koneksi matematis siswa. Sehingga diperoleh persentase ketuntasan klasikal siswa pada pre-test di uji coba II yaitu 50\% (17 siswa), sedangkan postest yaitu 88,2\% (30 orang) yang dikategorikan tinggi dalam koneksi matematis. Hal ini berarti, diperoleh gambaran bahwa pengembangan perangkat pembelajaran berbasis pendekatan realistik dapat meningkatkan kemampuan koneksi matematis. 
Dengan demikian, dapat disimpulkan dari beberapa hasil penelitian bahwa perangkat pembelajaran matematika berbasis pendekatan realistik yang dikembangkan dapat meningkatkan kemampuan koneksi matematis.

\section{Kualitas Perangkat Pembelajaran Berbasis Pendekatan Realistik}

Perangkat pembelajaran berbasis pendekatan realistik layak digunakan apabila dapat menimbulkan akibat, efek atau pengaruh yang signifikan terhadap pengguna perangkat pembelajaran ini. Kualitas perangkat pembelajaran meliputi valid, praktis dan efektif. Berdasarkan hasil yang diperoleh secara keseluruhan baik pada uji coba lapangan pertama dan kedua dapat disimpulkan bahwa perangkat pembelajaran matematika berbasis pendekatan realistik untuk meningkatkan kemampuan koneksi matematis dan kemandirian belajar siswa telah memenuhi batas keefektifan yang meliputi ketuntasan belajar siswa secara klasikal, kemampuan guru mengelola pembelajaran, aktivitas siswa selama pembelajaran dan respon siswa.

Disamping itu, berdasarkan penerapan perangkat pembelajaran matematika berbasis pendekatan realistik yang dilakukan, ditemukan kelemahan yaitu tidak semua siswa cepat dalam belajar dengan mengkonstruksi sendiri pengetahuan mereka. Sehingga terdapat beberapa siswa yang mengalami kesulitan dalam proses pembelajaran. Dengan demikian dapat disimpulkan bahwa kelemahan siswa dalam pendekatan realistik terdapat pada tahap siswa mengkonstruksi pengetahuannya sendiri.

Diperolehnya perangkat pembelajaran yang efektif, disebabkan karena perangkat pembelajaran yang dikembangkan dirancang sesuai dengan karakteristik dari pendekatan realistik, sehingga dapat memberikan kebebasan kepada siswa untuk membangun dan menemukan konsepkonsep matematika melalui masalah-masalah realistik yang diberikan, sehingga konsep matematika yang telah diperolehnya mampu bertahan lebih lama dalam pikiran siswa.

\section{KESIMPULAN}

Perangkat pembelajaran berbasis pendekatan realistik dalam meningkatkan kemampuan koneksi matematis siswa sudah efektif untuk digunakan dalam pembelajaran. Indikator efektivitas tersebut adalah: 1) 85\% siswa yang mengikuti tes kemampuan koneksi matematis memperoleh nilai minimal 75. 2) Pencapaian persentase waktu ideal aktivitas siswa. 3) Pencapaian kemampuan guru mengelola pembelajaran minimal cukup. 4) Minimal $80 \%$ dari banyak subjek yang diteliti memberikan respon yang positif terhadap komponen perangkat pembelajaran berbasis pendekatan realistik yang dikembangkan.

Peningkatan kemampuan koneksi matematis siswa menggunakan perangkat pembelajaran berbasis pendekatan realistik pada materi program linier adalah $(90,63-81,25) \%=9,38 \%$. Artinya rata-rata pencapaian kemampuan koneksi matematis siswa pada uji coba I sebesar $81,25 \%$ meningkat menjadi 90,63\% pada uji coba II. Disamping itu, rata-rata setiap indikator kemampuan koneksi matematis meningkat dari uji coba I ke uji coba II. Respon siswa terhadap komponen-komponen 
perangkat pembelajaran dan kegiatan pembelajaran adalah positif. Kemandirian belajar siswa meningkat dari uji coba I sampai uji coba II, dengan indikator kepercayaan diri dalam belajar, keingintahuan dalam mendalami materi yang dipelajari, ketekunan untuk bersemangat dan bergairah dalam berprestasi, fleksibilitas (kerjasama atau berbagi pengetahuan) dan reflektif atau rasa senang dalam belajar.

\section{UCAPAN TERIMA KASIH}

Terima kasih saya ucapkan kepada dosen pembimbing Bapak Prof. Dr. Bornok Sinaga, M.Pd dan Bapak Dr. Mulyono, M.Si. Terima kasih juga saya ucapkan untuk semua pihak yang membantu dalam menyelesaikan penelitian ini.

\section{REFERENSI}

Aisah, S., Kurniasih, D., \& Fitriani. (2018). Analisis Kemandirian Belajar Siswa padaa Mata Pelajaran Kimia di Kelas X SMA Negeri 3 Sintang. Ar-Razi Jurnal Ilmiah, 6(2), 76-86. https//doi.org/10.29406/ar-r.v6i2.1226

Aulia, L. N., Susilo, S., \& Subali, B. (2019). Upaya peningkatan kemandirian belajar siswa dengan model problem-based learning berbantuan media Edmodo. Jurnal Inovasi Pendidikan IPA, 5(1), 69-78. https://doi.org/10.21831/jipi.v5i1.18707

Danaryanti, A., \& Dara, T. (2016). Penerapan Model Problem Prompting Learning untuk Meningkatkan Kemampuan Koneksi Matematis Siswa SMP. EDU-MAT Jurnal Pendidikan Matematika, 4, 8-14.

Depdiknas. (2006). Panduan Pengembangan Bahan Ajar. Direktorat pembinaan SMA, Dirjen Mandikdasmen, Depdiknas.

Dewi, W. A. . (2020). Dampak Covid-19 Terhadap Implementasi Pembelajaran Daring di Sekolah Dasar. Edukatif: Jurnal Ilmu Pendidikan, 2(1), 55-61. doi: https://doi.org/10.31004/edukatif.v2i1.89

Dickinson, P \& Hough, S. (2012). Using Realistic Mathematics Education in UK Classrooms.

Fadhillah, N., \& Faradina, S. (2016). Hubungan kelekatan orangtua dengan kemandirian remaja SMA di Banda Aceh. Jurnal Ilmiah Mahasiswa Psikologi, 1(4). http://jim.unsyiah.ac.id/Psikologi/article/v iew/1429

Henriana, S. \& S. (2014). Mathematical Connection Ability And Self-Confidence (An Experiment On Junior High School Students Through Contextual Teaching And Learning With Mathematical Manipulative. International Journal of Education, 8(1).

Hudojo, H. (1994). Mengajar Belajar Matematika. Departemen Pendidikan dan Kebudayaan Direktorat Jendral Pendidikan Tinggi Proyek Pengembangan Lembaga Pendidikan dan Tenaga Kependidikan.

Rismawati, M., Irawan, E. B., \& Susanto, H. (2016). ANALISIS KESALAHAN KONEKSI 
Pengembangan Perangkat Pembelajaran Berbasis Pendekatan Matematika Realistik Untuk Meningkatkan Kemampuan Koneksi dan Kemandirian Belajar Siswa SMA Swasta Tunas Pelita Binjai, Nurliza Fahmi Lubis, Bornok Sinaga, Mulyono

MATEMATIS SISWA PADA MATERI SISTEM PERSAMAAN LINIER DUA VARIABEL. Konferensi Nasional Penelitian Matematika Dan Pembelajarannya (KNPMP I), 127-134.

Thiagarajan, Semmel, M. (1974). Instructional Development for Training Teachers of Exceptional Children. Central for Innovation on Teaching The Handicapped.

Yohanis, J., Triwiyono, Modouw, W. (2013). Pengembangan Modul Pembelajaran Fisika Bilingual Kelas X Pokok Bahasan Gerak Lurus di SMA Negeri 3 Jayapura. Urnal Ilmu Pendidikan Indonesia., I, 10-19. https://garuda.kemdikbud.go.id/author/view/575956

Yuliani, S., Tindangen, M., \& Rambitan, V. (2016). Analisis Permasalahan Guru Terkait Perangkat Pembelajaran Berbasis Model Pembelajaran Biologi Di SMA. Jurnal Pendidikan, 1(1), 20662070. 